Horban I. I., Hudyma A. A. The dynamics of abnormalities of the biochemical composition of bile under the influence of two-hour tourniquet limb ischemia and acute blood loss in the experiment. Journal of Education, Health and Sport. 2020;10(2):231-240. eISSN 2391-8306. DOI http://dx.doi.org/10.12775/JEHS.2020.10.02.028

https://apcz.umk.pl/czasopisma/index.php/JEHS/article/view/JEHS.2020.10.02.028

https://zenodo.org/record/3751822

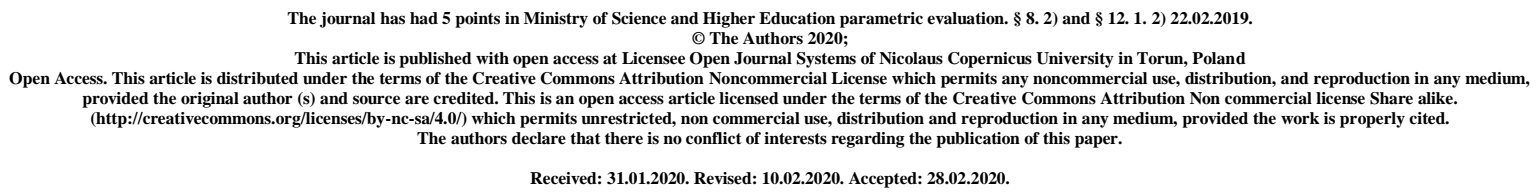

UDK 612.357:616-005.1/.-005.4]-092.9

\title{
THE DYNAMICS OF ABNORMALITIES OF THE BIOCHEMICAL COMPOSITION OF BILE UNDER THE INFLUENCE OF TWO-HOUR TOURNIQUET LIMB ISCHEMIA AND ACUTE BLOOD LOSS IN THE EXPERIMENT
}

\author{
I. I. Horban, A. A. Hudyma \\ Ivan Horbachevsky Ternopil National Medical University \\ of The Ministry of Health of Ukraine
}

\begin{abstract}
Introduction. Traumatism is one of the most current problems nowadays. Its increase is caused by the escalation in number of emergencies. In recent years the proliferation of frequency of terrorist attacks and local armed conflicts has been observed. Under those circumstances, the acute blood loss is considered to be the leading cause of injured people's death. An effective way of stopping a massive external haemorrhage from the limbs is applying the tourniquet which entirely ceases arterial blood flow. It is deemed that safe duration of tourniquet application is two hours. Individual authors' researches indicate the negative impact of post-tourniquet reperfusion on body. However, influence of the acute blood loss, which is complicated by limb ischemia-reperfusion, on the internal organs is insufficiently studied.

Objective of research: to establish peculiarities of the functional state of the liver under impact of two-hour tourniquet limb ischemia and acute blood loss in the experiment.

Materials of the research and their discussion. The experiments were conducted on
\end{abstract}


96 non-linear male rats weighing 200-220g. All animals were divided into four groups: control and three experimental ones. Injuries were inflicted under thiopental 1- sodium anesthesia. In the first experimental group, the limb ischemia-reperfusion injury was performed on animals by a method of applying a band of an elastic tourniquet SWAT-T. (USA), the width of $10 \mathrm{~mm}$, proximally to the rat's left paw for 120 minutes. Acute blood loss ( $20 \%$ of circulating blood volume) was performed by severing a femoral vein in the second experimental group. In the third experimental group, these lesions were combined. The control group included the animals, which were injected into anesthesia and subsequently were used for investigations in an hour.

An hour and two hours later, as well as in 1, 7 and 14 days, the functional state of the liver was determined in experimental animals through collecting the bile within an hour with a further determination of the total bile acids concentration, the cholesterol and calculation of the cholate-cholesterol coefficient.

Result of the research and their discussion. It was established that the two-hour exsanguination of the limb in the reperfusion period can negatively affect the functional state of the liver with a maximum of abnormalities after 3 hours. In comparison with the control group, the content of total bile acids in the bile appreciably decreased and the cholatecholesterol coefficient increased. Under the circumstances of the acute bleeding, the abnormalities were significantly greater. The reduction in the content of the total bile acids in bile and the cholate-cholesterol ratio was perceived at all periods of the observation as well as the increase in the content of the cholesterol after 1 and 7 days of the experiment, which indicate the dysfunctions in process of the bile acids synthesis from cholesterol and the amplification in lithogenic characteristics of bile. For the first time, it was shown that the combination of acute blood loss and limb ischemia-reperfusion exacerbated the dysfunction of functional state of the liver. Besides, a greater decrease in the content of total bile acids in bile, particularly in 3 hours, in 1 and 14 days of experiment, a significant increase in cholesterol content and a reduction in cholate-cholesterol coefficient after three hours of reperfusion period were observed.

Consequently, the two-hour tourniquet application in the condition of the acute blood loss in the amount of $20 \%$ of circulating blood volume aggravates the liver dysfunction in comparison to each of the effects in particular. This should be taken into consideration while assisting injured and affected people with acute blood loss from limbs, who were being applied with tourniquet. Our results aim at searching for efficacious tools of counteracting the impact of limb ischemia-reperfusion in conditions of acute blood loss. 
Conclusions. The complication of acute blood loss by limb ischemia-reperfusion is accompanied by a summation of their negative impact on the functional state of the liver with a maximum value after $3 \mathrm{~h}-1$ day of the experiment. Under these circumstances, in 3 hours, 1 and 14 days the content of total bile acids in bile is statistically probably lower compared to the experimental group in which the acute blood loss was solely performed. The increase in the content of the cholesterol in bile is observed as well as the reduction in cholesterol ratio that are statistically substantial after 3 hours of the experiment.

Key words: blood loss; tourniquet; ischemia; reperfusion; bile acids; choleterol.

Introduction. Traumatism is one of the most current problems nowadays. Traumas mortality ranks third in the whole world, being placed below the cardiovascular and cancer diseases. According to the World Health Organization (WHO), 2 millions people annually die of traumas and over 45 million people become disabled [1].

The spread of traumas in a modern urban society is caused by an increase in the number of emergencies of technological, natural, socio-political and military nature. In recent years the proliferation of frequency of terrorist attacks and local armed conflicts has been observed. [2]. Under those circumstances, the blood loss is considered to be the leading cause of injured people's' death [3]. An effective way of stopping a massive external haemorrhage from the limbs is applying the tourniquet which entirely ceases arterial blood flow. It is deemed that the safe duration of tourniquet application is two hours. [4]. Nevertheless, some authors have conducted that total exsanguination of the limb causes not only the tissue damage underneath the tourniquet, but is also accompanied by systemic disturbances, which are resulted of the penetration of toxins from the ischemic limb after its reperfusion in the bloodstream [5]. In the muscle tissue of the ischemic limb in conditions of the reperfusion the lipid peroxidation processes are being activated, the cell membrane destruction is being intensified as well as arising of the inflammation of the ischemia-induced local areas. However, in conditions of the acute blood loss, their impact on the internal organs is insufficiently studied.

The objective of the research: to elucidate peculiarities of the functional state of the liver under the impact of two-hour tourniquet limb ischemia and acute blood loss in the experiment.

Materials of the research and their discussion. The experiments were conducted on 96 non-linear male rats 200-220g in weight in accordance with the European Convention for the Protection of Vertebrate Animals used for Experimental and Other Scientific Purposes 
(European Convention, 1986).

All animals were divided into four groups: a control and three experimental ones (6 rats in each group). Injuries were inflicted under thiopental sodium anesthesia. In the first experimental group, limb ischemia-reperfusion injury was performed on animals by a method of applying a band of an elastic tourniquet SWAT-T (USA), the width of $10 \mathrm{~mm}$, proximally to the rat's left paw for 120 minutes. The tourniquet was tightened in accordance with placed integrated stretch indicator until the bleeding stopped entirely. Acute blood loss $(20 \%$ of circulating blood volume) was performed by severing a femoral vein in the second experimental group. In the third experimental group, these lesions were combined. The animals in the control group were injected into anesthesia using an equivalent dose of sodium thiopental, were applied a tourniquet for 2 hours without stopping the bloodstream, and subsequently were used for investigations in an hour.

An hour and two hours later, as well as in 1, 7 and 14 days, the functional state of liver was determined in the experimental animals. Under conditions of sodium thiopental anesthesia (60 mg. $\mathrm{kg}^{-1}$ of weight) in each experimental group the common bile duct was catheterized in animals and bile was collected for 60 minutes [6]. In bile samples, the content of the total bile acids as well as the cholesterol was determined and the cholate-cholesterol coefficient (the total bile acids/the cholesterol) was calculated that denotes the lithogenic characteristics of bile. After bile collection, the animals were removed from the experiment by means of bloodletting directly from the heart that corresponded to $2 \mathrm{~h}$ and $3 \mathrm{~h}$ of reperfusion in the early period of the experiment.

The estimation of the probability of differences between the experimental groups was performed using the non-parametric Mann-Whitney test.

Results of the research and their discussion. Studies have shown that in the first experimental group after two hours of the reperfusion period the content of the total bile acids in bile (table 1), in comparison to the control group, remained virtually unaltered $(p>0,05)$. However, after 3 hours, the index became considerably lower compared to the control group (by $20,1 \%, \mathrm{p}<0,05$ ) and previous observation period (by $10,0 \%, \mathrm{p}<0,05$ ). The index subsequently increased and did not significantly differ from the level of the control group ( $p>0,05)$. Under conditions of acute blood loss, the content of total bile acids in bile was statistically probably lower at all observation periods compared to the control group $(\mathrm{p}<0,05)$. In the dynamics, the index to the 1 day of reperfusion period reached its minimum value, up to 14 days increased, exceeding the outcome of previous observation terms $(p<0,05)$. Under 
circumstances of a compound of limb ischemia-reperfusion and acute blood loss, the content of the total bile acids in bile at all observation terms was also significantly lower compared to the control group. The index reached its minimum value after 1 day, increased by 14th day and became markedly higher than in previous observation terms. $(p<0,05)$.

Table 1 - The dynamic of the content of total bile acids in bile $\left(\mathrm{g} \cdot \mathrm{l}^{-1}\right)$ after acute blood loss complicated by limb ischemia-reperfusion (Me (LQ;UQ)) - median (lower and upper quartile)

\begin{tabular}{|c|c|c|c|c|c|}
\hline \multirow{2}{*}{ Experimental group } & \multicolumn{5}{|c|}{ Duration of the reperfusion period } \\
\hline & 2 hours & 3 hours & 1 day & 7 days & 14 days \\
\hline \multicolumn{6}{|c|}{ Control group $=1,69(1,54 ; 1,78)(n=6)$} \\
\hline $\begin{array}{l}\text { Group 1 } \\
\text { Ischemia- } \\
\text { reperfusion }\end{array}$ & $\begin{array}{c}1,50 \\
(1,50 ; 1,61) \\
(\mathrm{n}=6)\end{array}$ & $\begin{array}{c}1,35^{* 2 g} \\
(1,24 ; 1,46) \\
(n=6)\end{array}$ & $\begin{array}{c}1,46 \\
(1,37 ; 1,73) \\
(n=6)\end{array}$ & $\begin{array}{c}1,65^{3 g} \\
(1,54 ; 1,88) \\
(n=6)\end{array}$ & $\begin{array}{c}1,73^{3 \mathrm{~g}} \\
(1,65 ; 1,80) \\
(\mathrm{n}=6)\end{array}$ \\
\hline \begin{tabular}{|l|} 
Group 2 \\
Blood loss
\end{tabular} & $\begin{array}{c}1,13^{*} \\
(1,05 ; 1,20) \\
(\mathrm{n}=6)\end{array}$ & $\begin{array}{c}1,09^{*} \\
(1,05 ; 1,18) \\
(n=6)\end{array}$ & $\begin{array}{c}1,01^{*} \\
(0,92 ; 1,16) \\
(n=6)\end{array}$ & $\begin{array}{c}1,28^{*} \\
(1,09 ; 1,35) \\
(n=6)\end{array}$ & $\begin{array}{c}1,43^{* 2 \mathrm{~g}, 3 \mathrm{~g}, 1 \mathrm{~d}} \\
(1,35 ; 1,50) \\
(\mathrm{n}=6)\end{array}$ \\
\hline $\begin{array}{l}\text { dGroup } 3 \\
\text { Ischemia- } \\
\text { reperfusion+blood } \\
\text { loss }\end{array}$ & $\begin{array}{c}0,98^{*} \\
(0,90 ; 1,05) \\
(\mathrm{n}=6)\end{array}$ & $\begin{array}{c}0,83^{*} \\
(0,75 ; 0,96) \\
(n=6)\end{array}$ & $\begin{array}{c}0,79^{* 2 g} \\
(0,72 ; 0,88) \\
(n=6)\end{array}$ & $\begin{array}{c}1,20 * 2 \mathrm{~g}, 3 \mathrm{~g}, 1 \mathrm{~d} \\
(1,14 ; 1,31) \\
(\mathrm{n}=6)\end{array}$ & $\begin{array}{c}1,24^{* 2 \mathrm{~g}, 3 \mathrm{~g}, 1 \mathrm{~d}} \\
(1,20 ; 1,33) \\
(\mathrm{n}=6)\end{array}$ \\
\hline $\mathrm{p}_{1-2}$ & $<0,05$ & $<0,05$ & $<0,05$ & $<0,05$ & $<0,05$ \\
\hline $\mathrm{p}_{1-3}$ & $<0,05$ & $<0,05$ & $<0,05$ & $<0,05$ & $<0,05$ \\
\hline $\mathrm{p}_{2-3}$ & $>0,05$ & $<0,05$ & $<0,05$ & $>0,05$ & $<0,05$ \\
\hline
\end{tabular}

Notes:

$1 .^{*}$ - differences concerning the control group are statistically plausible $(\mathrm{p}<0,05)$;

2. $\mathrm{p}_{1-2}$ - the plausibility of differences between the experimental groups 1 and $2 ;$;

3. $\mathrm{p}_{1-3}$ - the plausibility of differences between the experimental groups 1 and $3 ;$;

4. $\mathrm{p}_{2-3}-$ - the plausibility of differences between experimental groups 2 and 3;

5. ${ }^{2 \mathrm{~g}, 3 \mathrm{~g}, 1 \mathrm{~d}, 7 \mathrm{~d}}$ - differences concerning $2 \mathrm{~h}$ and $3 \mathrm{~h}$ as well as 1 day and 7 days respectively are statistically plausible $(\mathrm{p}<0,05)$.

Comparison of the experimental groups with each other denoted that at all observation periods in the experimental group 1 the content of total bile acids in bile was statistically probably lower than in experimental groups 2 and $3\left(\mathrm{p}_{1-2}<0,05, \mathrm{p}_{1-3}<0,05\right)$. The complication of acute blood loss by limb ischemia (experimental group 3) in the reperfusion period, in comparison with the experimental group 2, caused a greater decrease in the content of total bile acids in bile that was statistically significant after $3 \mathrm{~h}, 1$ and 14 days of the experiment (by 23,8, 21,8 i 13,3\%, respectively, $\mathrm{p}_{2-3}<0,05$ ).

The content of the cholesterol in bile (table 2), meanwhile, under conditions of limb 
ischemia-reperfusion (experimental group 1) did not change appreciably during the experiment in comparison with the control group $(p>0,05)$. After performing the acute blood loss (experimental group 2) the index increased and after 1 and 7 days became substantially higher than in the control group (by 33,7 and 20,0\%, respectively, $\mathrm{p}<0,05$ ). After 14 days the index reduced, reaching the control level $(p>0,05)$ and was probably lower than after 1 and 7 days of observation. $(\mathrm{p}<0,05)$. In the experimental group 3 (acute blood loss in combination with limb ischemia-reperfusion) after three hours of the experiment the content of the cholesterol in bile became statistically probably higher than in the control group (by $48,1 \%$, $\mathrm{p}<0,05)$. The index, thereafter, declined, reaching the control level $(\mathrm{p}>0,05)$ and was significantly lower than after 3 hours of observation.

Table 2 - The dynamic of the cholesterol content in bile $\left(\mathrm{g} \cdot \mathrm{l}^{-1}\right)$ after acute blood loss, complicated by limb ischemia reperfusion (Me (LQ;UQ)) - median (lower and upper quartile)

\begin{tabular}{|l|c|c|c|c|c|}
\hline \multirow{2}{*}{ Experimental group } & \multicolumn{5}{|c|}{ Duration of the reperfusion period } \\
\cline { 2 - 6 } & 2 hours & 3 hours & 1 day & 7 days & 14 days \\
\hline \multicolumn{7}{|c|}{ Control group $=1,69$} \\
$(1,54 ; 1,78)(\mathrm{n}=6)$ \\
\hline $\begin{array}{l}\text { Group 1 } \\
\text { Ischemia- } \\
\text { reperfusion }\end{array}$ & $\begin{array}{c}0,25 \\
(0,21 ; 0,26) \\
(\mathrm{n}=6)\end{array}$ & $\begin{array}{c}0,25 \\
(0,21 ; 0,27) \\
(\mathrm{n}=6)\end{array}$ & $\begin{array}{c}0,26 \\
(0,22 ; 0,28) \\
(\mathrm{n}=6)\end{array}$ & $\begin{array}{c}0,23 \\
(0,20 ; 0,27) \\
(\mathrm{n}=6)\end{array}$ & $\begin{array}{c}0,19 ; 0,26) \\
(\mathrm{n}=6)\end{array}$ \\
\hline $\begin{array}{l}\text { Group 2 } \\
\text { Blood loss }\end{array}$ & $\begin{array}{c}0,27 \\
(0,22 ; 0,30) \\
(\mathrm{n}=6)\end{array}$ & $\begin{array}{c}0,29 \\
(0,23 ; 0,30) \\
(\mathrm{n}=6)\end{array}$ & $\begin{array}{c}0,31^{*} \\
(0,28 ; 0,31) \\
(\mathrm{n}=6)\end{array}$ & $\begin{array}{c}0,28^{*} \\
(0,27 ; 0,29) \\
(\mathrm{n}=6)\end{array}$ & $\begin{array}{c}0,25^{1 \mathrm{~d}, 7 \mathrm{~d}} \\
(0,23 ; 0,26) \\
(\mathrm{n}=6)\end{array}$ \\
\hline $\begin{array}{l}\text { Group 3 } \\
\text { Ischemia- } \\
\text { reperfusion+blood } \\
\text { loss }\end{array}$ & $\begin{array}{c}0,28 \\
(0,25 ; 0,31) \\
(\mathrm{n}=6)\end{array}$ & $\begin{array}{c}0,34^{* 2 \mathrm{~g}} \\
(0,32 ; 0,36) \\
(\mathrm{n}=6)\end{array}$ & $\begin{array}{c}0,25^{3 \mathrm{~g}} \\
(0,24 ; 0,29) \\
(\mathrm{n}=6)\end{array}$ & $\begin{array}{c}0,26^{3 \mathrm{~g}} \\
(0,23 ; 0,28) \\
(\mathrm{n}=6)\end{array}$ & $\begin{array}{c}0,23 ; \\
(\mathrm{n}=6)\end{array}$ \\
\hline $\mathrm{p}_{1-2}$ & $>0,05$ & $>0,05$ & $>0,05$ & $>0,05$ & $>0,05$ \\
\hline $\mathrm{p}_{1-3}$ & $>0,05$ & $<0,05$ & $>0,05$ & $>0,05$ & $>0,05$ \\
\hline $\mathrm{p}_{2-3}$ & $>0,05$ & $<0,05$ & $<0,05$ & $>0,05$ & $>0,05$ \\
\hline
\end{tabular}

Comparison of the experimental groups with each other illustrated that after 2 hours as well as 1, 7 and 14 days of the experiment no significant differences in the content of the cholesterol in bile were perceived $\left(\mathrm{p}_{1-2}>0,05, \mathrm{p}_{1-3}>0,05, \mathrm{p}_{2-3}>0,05\right)$. However, after 3 hours, the content of the cholesterol in bile was appreciably higher in experimental group 3 than in experimental groups 1 and 2 (by 36,0 and 17,2\% relatively, $\mathrm{p}_{1-3}<0,05, \mathrm{p}_{2-3}<0,05$ ).

The analysis of cholato-cholesterol ratio dynamics demonstrated ( table 3 ) that after 3 hours and 1 day of the reperfusion period the index became statistically probably lower in the 
experimental group 1 than in the control group (by 21,9 i $21,4 \%$ relatively, $p<0,05$ ). The index subsequently increased, reaching the control level $(\mathrm{p}>0,05)$. In the experimental group 2 , the cholate-cholesterol ratio at all observation periods was substantially lower than in the control group. In the dynamics, the index to the 1 day reduced and subsequently increased, moreover, became statistically probably higher after 14 days than in a $3 \mathrm{~h}$, after 1 and 7 days of the experiment $(\mathrm{p}<0,05)$. In the experimental group 3 , the dynamics of the cholatecholesterol ratio was analogous. The index was significantly lower than the control at all observation times $(p<0,05)$, reached its minimum value after three hours of reperfusion period in the dynamics, after 7 and 14 days increased and became appreciably higher than in the previous observation times $(\mathrm{p}<0,05)$.

Table 3 - The dynamic of the cholato-cholesterol coefficient (CU) after acute blood loss, complicated by limb ischemia-reperfusion (Me (LQ;UQ)) - (lower and upper quartile)

\begin{tabular}{|c|c|c|c|c|c|}
\hline \multirow{2}{*}{$\begin{array}{l}\text { Experimental } \\
\text { group }\end{array}$} & \multicolumn{5}{|c|}{ Duration of the reperfusion period } \\
\hline & 2 hours & 3 hours & 1 day & 7 days & 14 days \\
\hline \multicolumn{6}{|c|}{ Control group $=7,58(7,25 ; 8,20)(n=6)$} \\
\hline $\begin{array}{l}\text { Group 1 } \\
\text { Ischemia- } \\
\text { reperfusion }\end{array}$ & $\begin{array}{c}6,76 \\
(5,69 ; 7,38) \\
(\mathrm{n}=6)\end{array}$ & $\begin{array}{c}5,92^{* 2 \mathrm{~g}} \\
(4,80 ; 6,43) \\
(\mathrm{n}=6)\end{array}$ & $\begin{array}{c}5,96^{*} \\
(5,10 ; 7,02) \\
(n=6)\end{array}$ & $\begin{array}{c}7,58 \\
(6,43 ; 8,40) \\
(n=6)\end{array}$ & $\begin{array}{c}7,66 \\
(6,20 ; 9,39) \\
(n=6)\end{array}$ \\
\hline $\begin{array}{l}\text { Group } 2 \\
\text { Blood loss }\end{array}$ & $\begin{array}{c}4,23^{*} \\
(3,52 ; 5,40) \\
(n=6)\end{array}$ & $\begin{array}{c}3,61^{*} \\
(3,24 ; 5,16) \\
(\mathrm{n}=6)\end{array}$ & $\begin{array}{c}3,58^{*} \\
(3,03 ; 4,18) \\
(n=6)\end{array}$ & $\begin{array}{c}4,58^{*} \\
(3,97 ; 4,68) \\
(n=6)\end{array}$ & 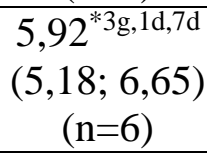 \\
\hline $\begin{array}{l}\text { Group } 3 \\
\text { Ischemia- } \\
\text { reperfusion+blood } \\
\text { loss } \\
\end{array}$ & $\begin{array}{c}3,70^{*} \\
(2,79 ; 4,41) \\
(\mathrm{n}=6)\end{array}$ & $\begin{array}{c}2,40^{*} \\
(2,21 ; 2,80) \\
(\mathrm{n}=6)\end{array}$ & $\begin{array}{c}3,08^{*} \\
(2,57 ; 3,17) \\
(n=6)\end{array}$ & $\begin{array}{c}4,72^{* 3 \mathrm{~g}, 1 \mathrm{~d}} \\
(4,27 ; 5,40) \\
(\mathrm{n}=6)\end{array}$ & $\begin{array}{c}5,18^{* 2 \mathrm{~g}, 3 \mathrm{~g}, 1 \mathrm{~d}} \\
(0,23 ; 0,27) \\
(\mathrm{n}=6)\end{array}$ \\
\hline $\mathrm{p}_{1-2}$ & $<0,05$ & $>0,05$ & $<0,05$ & $<0,05$ & $>0,05$ \\
\hline $\mathrm{p}_{1-3}$ & $<0,05$ & $<0,05$ & $<0,05$ & $<0,05$ & $<0,05$ \\
\hline $\mathrm{p}_{2-3}$ & $>0,05$ & $<0,05$ & $>0,05$ & $>0,05$ & $>0,05$ \\
\hline
\end{tabular}

Comparison of the experimental groups with each other illustrated that after $2 \mathrm{~h}, 1$ and 7 days of the experiment the rate of the cholate-cholesterol ratio was statistically probably lower in the experimental group 2 and 3 than in the $1^{\text {st }}$ one $\left(\mathrm{p}_{1-2}<0,05, \mathrm{p}_{1-3}<0,05\right)$. After 3 days in the experimental group 3, the index became significantly lower than in the experimental groups 1 and 2 (by 59,4 i 33,5\%, relatively, $\mathrm{p}_{1-3}<0,05, \mathrm{p}_{2-3}<0,05$ ). After 14 days the index kept significantly lower in the experimental group 3 than in the $1^{\text {st }}$ experimental one (by $\left.32,4 \%, \mathrm{p}_{1-3}<0,05\right)$. 
The results ascertain that the two-hour limb exsanguination in the reperfusion period can negatively affect the functional state of the liver with a maximum of abnormalities after 3 hours. It is revealed by a reduction in the content of total bile acids in bile and an increase in the cholate-cholesterol ratio.

The bile acids pool, that are excreted with bile, is known to consists of those, which are synthesized from cholesterol in the microsomal system of hepatocytes and which are transported back to the liver due to enterohepatic recirculation [7]. Taking into consideration the membranedependence of the processes of bile acids synthesis and their transport in the hepatocytes, it can be presumed that in experimental group 1 revealed dysfunctions were caused by negative effect of endotoxins, which are released from the ischemic limb after its reperfusion, on the state of the hepatocyte subcellular membranes, primarily of endoplasmic reticulum, where the bile acid synthesis occurs. Under conditions of acute blood loss abnormalities were considerably greater. The reduction in the content of total bile acids in bile and the the cholate-cholesterol ratio was perceived at all periods of the observation as well as the increase in the content of the cholesterol in 1 and 7 days, which indicates the dysfunctions in processes of bile acids synthesis from cholesterol and the enhancement in lithogenic characteristics of bile. Obviously, it is caused by the reduction in arterial pressure, the decrease in organ perfusion and the development of hypoxia. Under those conditions, the formation of active oxygen species is intensified that stimulates the processes of lipid peroxidation and oxidative protein modification primarily subcellular membranes of hepatocytes with a decrease in their functions [8]

It was done firstly that combination of the acute blood loss and limb ischemiareperfusion exacerbated the dysfunctions of the functional state of the liver. Furthermore, a greater decrease in the content of total bile acids in bile, particularly in 3 hours, in 1 and 14 days of experiment, a significant increase in cholesterol content and a reduction in cholatecholesterol coefficient after the three-hour reperfusion period were observed. It can be assumed that under these conditions pathogenic mechanisms of acute blood loss, ischemia and reperfusion of the limb are layered.

Accordingly, the two-hour tourniquet application in the condition of the acute blood loss in the amount of $20 \%$ of circulating blood volume aggravates the liver dysfunction in comparison to each of the effects in particular. This should be taken into consideration while assisting injured and affected people with acute blood loss from limbs, who were being applied with tourniquet. Our results aim at searching for efficacious tools of counteracting the impact of limb ischemia-reperfusion in conditions of acute blood loss. 


\section{Conlusions}

1. The two-hour limb ischemia in the reperfusion period is accompanied by a significant decrease in the content of total bile acids in bile as well as in cholate-cholesterol coefficient that reaches its minimum value after $3 \mathrm{~h}-1$ day of the experiment and returns to the control level in 7 days.

2. After performing the acute blood loss, the amplitude of the abnormalities in the content of total bile acids in bile and cholate-cholesterol ratio at all observation periods is statistically probably higher than under conditions of the ischemia-reperfusion, besides, the content of the cholesterol is appreciably increases after 1 and 7 days.

3. The complication of acute blood loss by limb ischemia-reperfusion is accompanied by a summation of their negative effect on the functional state of the liver with a maximum value after $3 \mathrm{~h}-1$ day of the experiment. Under these conditions, in 3 hours, 1 and 14 days the content of total bile acids in bile is statistically probably lower compared to the experimental group in which the acute blood loss was solely performed. The increase in the content of the cholesterol in bile is observed as well as the reduction in cholesterol ratio that are statistically substantial after 3 hours of the experiment.

\section{References:}

1. Management of the patients with blunt renal trauma: 20 years of clinical experience / L. P. Sarychev, Y. V. Sarychev, H. L. Pustovoyt et al. Wiadomości Lekarskie. 2018. Vol.71(3 pt. 2). P. 719-722.

2. Global Terrorism Index. - Available at: http://economicsandpeace.org/wpcontent/uploads/2015/11/2015-Global-Terrorism-Index-Report.pdf

3. Elster EA, Frank KB, Todd ER. Implications of Combat Casualty Care for Mass Casualty Events. JAMA. 2013;310(5):475-476.

4. Efficacy of Prehospital Application of Tourniquets and Hemostatic Dressings To Control Traumatic External Hemorrhage. - Available at: https://www.ems.gov/pdf/research/Studies-andReports/Prehospital_Applications_Of_Tourniquest_And_Hemostatic_Dressings.pdf

5. Televjak A.T. (2018) Dynamika pokaznykiv perekysnogho okyslennja lipidiv ta antyoksydantnogho zakhystu v m'jazovij tkanyni zadnikh kincivok shhuriv pry rozvytku ishemichno-reperfuzijnogho syndromu (eksperymentaljne doslidzhennja) [The dynamic of indicators of lipid peroxidation and antioxidant protection in muscle tissue of the hind limbs 
of the rats in development of the ischemic-reperfusion syndrome (experimental study)]. Achievements of Clinical and Experimental Medicine. vol.3, pp. 132-139.

6. Droghovoz S.M., Ghubsjkyj Ju.I, Skakun M.P, Kovalenko V.M, Derymedvidj L.V (2001) Eksperymentaljne vyvchennja kholespazmolitychnoji, kholelitiaznoji ta ghepatoprotektornoji aktyvnosti novykh likarsjkykh zasobiv [Experimental study of cholospasmolytic, cholelithiasis and hepatoprotective activity of new medicine], in : Stefanov, O. V. (ed.). Doklinichni doslidzhennia likarskykh zasobiv: metodychni rekomendatsii [Preclinical research of medicinal products: methodical recommendations]. Kyiv: Avitsena, pp. 334-351.

7. Chekman I. S., Posohova E. A., Beregovaya E. G. (1996) Mikrosomalnaya fermentnaya sistema oranizma [The microsomal enzyme system of the body]. Kyiv, $80 \mathrm{p}$. 8. Volotovsjka N. V., Ghudyma A. A. (2011) Rolj ghemichnoji ghipoksiji v patoghenezi porushenj zhovchoutvorjuvaljnoji i zhovchovydiljnoji funkciji pechinky a tli skeletnoji travmy $\mathrm{v}$ rannjomu posttravmatychnomu periodi [The role of hemic hypoxia in the pathogenesis of disorders of the biligenic and bile-excreting functions of the liver and associated with skeletal 146 trauma in the early post-traumatic period]. Achievements of Clinical and Experimental Medicine, vol. 2 , no.15, pp. 31-33. 